\title{
THEORETICAL AND MÖSSBAUER EFFECT STUDY OF MAGNETIC AND ELECTRONIC PROPERTIES OF $\mathrm{Fe}_{3} \mathrm{Al}$ COMPOUND
}

\author{
J. Deniszczyk and J.E. Frackowiak \\ Institute of Physics and Chemistry of Metals, Silesian University \\ Bankowa 12, 40-007 Katowice, Poland
}

The electronic properties of $\mathrm{Fe}_{3} \mathrm{Al}$ were determined experimentally, with the use of the Mössbauer spectroscopy, and theoretically. The band structure of the compounds was investigated applying the self-consistent tight-binding linear muffin tin orbital method. The calculated Fermi contact term of hyperfine fields and the isomer shifts are in good agreement with the values resulting from analysis of experimental data. The different kinds of electron transfer estimated on the base of the proposed "additive model" are also strongly supported by calculations.

PACS numbers: $75.50 . \mathrm{Bb}, 76.80 .+\mathrm{y}$

Iron-aluminium alloys (up to 50 at.\% $\mathrm{Al}$ ) offer excellent opportunities for the study of magnetic properties and electron transfer between constituents as a function of type as well as degree of atomic order. The crystal structures of these alloys are all founded on the bcc lattice. The arrangement in this lattice depends on the composition, thermal and mechanical treatment. Two of these configurations are the ordered $\mathrm{B} 2$ structure of $\mathrm{FeAl}$ and $\mathrm{DO}_{3}$ structure of $\mathrm{Fe}_{3} \mathrm{Al}$ compounds. Within the unit cell of $\mathrm{FeAl}$ compound iron atom is surrounded by eight $\mathrm{Al}$ atoms. In $\mathrm{DO}_{3}$ structure unit cell there are two types of iron atom. The first, denoted by $\mathrm{Fe}(\mathrm{I})$, surrounded by eight iron atoms and the other, denoted by $\mathrm{Fe}(\mathrm{II})$, surrounded by four aluminium and four iron atoms (see Fig. 1 in Ref. [1]). The experimental lattice constant of $\mathrm{FeAl}$ and $\mathrm{Fe}_{3} \mathrm{Al}$ is $29.09 \mathrm{~nm}$ and $57.92 \mathrm{~nm}$, respectively.

The Mössbauer and free positron lifetime measurements of $\mathrm{Fe}_{3} \mathrm{Al}$ suggest that the electron density at $\mathrm{Fe}(\mathrm{I})$ atoms is slightly reduced relatively to that of pure $\alpha$-Fe. The isomer shift values for $\mathrm{Fe}(\mathrm{I})$ and $\mathrm{Fe}(\mathrm{II})$ are equal to $0.044 \mathrm{~mm} / \mathrm{s}$ and $0.184 \mathrm{~mm} / \mathrm{s}$, respectively [2-4]. On the base of the Mössbauer spectroscopy data a phenomenological model (the so-called additive model) which describes the change of electronic structure of $\mathrm{Fe}$ atoms in $\mathrm{Fe}-\mathrm{Al}$ system was proposed [4]. Two kinds of electron transfer were considered: (i) an intraatomic $4 s-3 d$ electron conversion, (ii) a transfer of $s(p)$ electrons from neighbouring $\mathrm{Al}$ atoms to the $3 d$-band of 
Fe atoms. An interatomic electron transfer from $\mathrm{Fe}(\mathrm{I})$ to $\mathrm{Fe}(\mathrm{II})$ atom was also postulated for explaining the experimental observations. The model relates the isomer shift and the difference in the hyperfine magnetic field $\Delta B_{\mathrm{hf}}$ relatively to $\alpha$-Fe with the change in number of $3 d\left(Q_{d}\right)$ and $4 s\left(Q_{s}\right)$ electrons in iron by the formula $\Delta B_{\mathrm{hf}}=A_{s} Q_{s}+A_{d} Q_{d}$ and $\Delta I S=-2 Q_{s}+0.2 Q_{d}$, where $A_{s}=$ $130.90 \mathrm{MA} / \mathrm{m}$ and $A_{d}=-6.76 \mathrm{MA} / \mathrm{m}$ are the hyperfine field coupling constants for the $4 s$ and $3 d$ electrons, respectively.

The bcc $\mathrm{Fe}-\mathrm{Al}$ alloy as well as $\mathrm{FeAl}$ and $\mathrm{Fe}_{3} \mathrm{Al}$ compounds have been the subject of theoretical investigations with the use of band structure methods $[1,5-7]$. Cluster calculations of Elzain and Yousif [7] for $\mathrm{Fe}-\mathrm{Al}$ bcc alloy reveal existence of electron transfer between constituents. The $3 d$ occupation of iron increases with the rate 0.07 electrons per $\mathrm{Al}$ in the nearest neighbour (NN) shell. Some information on the interatomic electronic transfers within the unit cell of $\mathrm{FeAl}$ and $\mathrm{Fe}_{3} \mathrm{Al}$ compounds can be found in the work of Müller et al. [5] and Ishida et al. [1]. Calculations for $\mathrm{FeAl}$ compound have shown that $\mathrm{Fe}$ atoms gain electrons at the cost of aluminium [5]. According to results of Ishida et al. for $\mathrm{Fe}_{3} \mathrm{Al}$ the aluminium atoms lose some portion of electrons, while the $\mathrm{Fe}$ (I) and $\mathrm{Fe}$ (II) atoms gain electrons.

It was interesting to calculate electronic structure of $\mathrm{FeAl}$ and $\mathrm{Fe}_{3} \mathrm{Al}$ compounds once more with an emphasize put on electron transfer within the unit cell. We performed the self-consistent spin-polarized calculations based on the tight binding-linear muffin tin orbitals method in the scalar-relativistic approximation [8]. The method treats the crystal according to the atomic sphere approximation (ASA). The calculated electron transfers are very sensitive to the choice of Wigner-Seitz (W-S) sphere radii. We performed band structure calculations with the use of two sets of radii. For one of them $\left(r_{\mathrm{WS}}^{\mathrm{Fe}}=13.83 \mathrm{~nm}\right.$ in $\mathrm{FeAl}, r_{\mathrm{WS}}^{\mathrm{Fe}(\mathrm{I})}=14.05 \mathrm{~nm}$ and $r_{\mathrm{WS}}^{\mathrm{Fe}(\mathrm{II})}=14.04 \mathrm{~nm}$ in $\mathrm{Fe}_{3} \mathrm{Al}$ ) the charge neutrality of $\mathrm{W}-\mathrm{S}$ spheres is preserved. The second set of $\mathrm{W}-\mathrm{S}$ radii, $r_{\mathrm{WS}}^{\mathrm{Fe}}=14.91 \mathrm{~nm}$ in FeAl, $r_{\mathrm{WS}}^{\mathrm{Fe}(\mathrm{I})}=13.62 \mathrm{~nm}$ and $r_{\mathrm{WS}}^{\mathrm{Fe}(\mathrm{II})}=14.69 \mathrm{~nm}$ in $\mathrm{Fe}_{3} \mathrm{Al}$, is chosen within the so-called "zero step potential approach" (the discontinuity of the effective potential at W-S spheres of the inequivalent atoms within unit cell is removed). In the calculations experimental values of lattice constants were used. For calculations of $\alpha$-Fe the lattice constant was taken equal to $28.7 \mathrm{~nm}\left(r_{\mathrm{WS}}^{\alpha-\mathrm{Fe}}=14.13 \mathrm{~nm}\right)$. The hyperfine field was calculated according to relativistic formula given by Blügel et al. [9] in which the average spin density over the Thomson sphere is taken into account. The isomer shift is calculated with the use of the formula $I S=-0.24 \Delta \rho_{4 s}(0)$, neglecting the contribution of core electrons (which contribute only in $10 \%$ [10]).

The quantitative results of the calculations for $\alpha-\mathrm{Fe}, \mathrm{FeAl}$ and $\mathrm{Fe}_{3} \mathrm{Al}$ are summarized in Tables I and II. Having analysed partial occupation numbers given in Table I the following observations concerning electron transfers can be made. Within the charge neutrality approach (interatomic electron transfer less than $10^{-7}$ electrons) it is evident that the presence of $\mathrm{Al}$ atoms within $\mathrm{NN}$ shell of iron forces the intraatomic $4 s(p)-3 d$ electron conversion. This process leads to the increase in $d$-states occupation number by 0.202 for $\mathrm{Fe}$ in $\mathrm{FeAl}(8 \mathrm{NN} \mathrm{Al})$ and by 0.086 for $\mathrm{Fe}(\mathrm{II})$ in $\mathrm{Fe}_{3} \mathrm{Al}$ (4 NN Al). $\mathrm{For} \mathrm{Fe}(\mathrm{I})$ in $\mathrm{Fe}_{3} \mathrm{Al}$, with no nearest 
TABLE I

The partial occupation numbers $\left(n_{l}\right)$, local magnetic moment $(M)$ and the total electron transfer $(\Delta Q)$ for $\mathrm{Fe} \mathrm{W}-\mathrm{S}$ spheres in pure $\alpha$ - $\mathrm{Fe}, \mathrm{FeAl}$ and $\mathrm{Fe}_{3} \mathrm{Al}$ compounds (negative values of $\Delta Q$ indicate the outward electron transfer). Data in brackets $(\ldots)$ represent the results of charge neutrality approach.

\begin{tabular}{c|c|c|c|c|c|c|c}
\hline \hline & Spin & $n_{s}$ & $n_{p}$ & $n_{d}$ & $n_{\text {tot }}$ & $M\left[\mu_{\mathrm{B}}\right]$ & $\Delta Q$ \\
\hline $\mathrm{Fe}$ & $\uparrow$ & 0.313 & 0.364 & 4.451 & 5.128 & 2.26 & - \\
(in $\alpha$-Fe) & $\downarrow$ & 0.328 & 0.426 & 2.118 & 2.872 & & \\
\hline $\mathrm{Fe}$ & $\uparrow+\downarrow$ & 0.682 & 0.942 & 7.063 & 8.688 & - & +0.688 \\
(in $\mathrm{FeAl})$ & & $(0.544)$ & $(0.685)$ & $(6.771)$ & $(8.000)$ & - & $(-)$ \\
\hline & $\uparrow$ & 0.284 & 0.321 & 4.463 & 5.068 & & \\
$\mathrm{Fe}(\mathrm{I})$ & & $(0.314)$ & $(0.371)$ & $(4.495)$ & $(5.180)$ & 2.43 & -0.295 \\
$\left(\right.$ in $\left.\mathrm{Fe}{ }_{3} \mathrm{Al}\right)$ & $\downarrow$ & 0.291 & 0.360 & 1.986 & 2.637 & $(2.36)$ & $(-)$ \\
& & $(0.322)$ & $(0.417)$ & $(2.082)$ & $(2.821)$ & & \\
& $\uparrow$ & 0.328 & 0.434 & 4.357 & 5.119 & & \\
$\mathrm{Fe}(\mathrm{II})$ & & $(0.286)$ & $(0.360)$ & $(4.290)$ & $(4.936)$ & 1.82 & +0.413 \\
$\left(\right.$ in $\left.\mathrm{Fe} e_{3} \mathrm{Al}\right)$ & $\downarrow$ & 0.339 & 0.488 & 2.467 & 3.294 & $(1.87)$ & $(-)$ \\
& & $(0.295)$ & $(0.403)$ & $(2.366)$ & $(3.064)$ & &
\end{tabular}

TABLE II Calculated values of hyperfine field $B_{\mathrm{hf}}$ (decomposed into core and valence electron contribution), 4s-charge density at iron nucleus $\rho_{4 s}(0)$ and the difference of hyperfine field $\Delta B_{\mathrm{h} f}$ and isomer shift $\Delta I S$ relatively to the $\alpha$-Fe.

\begin{tabular}{|c|c|c|c|c|c|c|}
\hline & \multicolumn{3}{|c|}{$B_{\mathrm{hf}}[\mathrm{MA} / \mathrm{m}]$} & \multirow{2}{*}{$\begin{array}{c}\Delta B_{\mathrm{hf}} \\
{[\mathrm{MA} / \mathrm{m}]}\end{array}$} & \multirow{2}{*}{$\begin{array}{c}\rho_{4 s}(0) \\
{\left[\text { a.u. }{ }^{-3}\right]}\end{array}$} & \multirow{2}{*}{$\begin{array}{c}\Delta I S \\
{[\mathrm{~mm} / \mathrm{s}]}\end{array}$} \\
\hline & core & valence & total & & & \\
\hline $\mathrm{Fe}($ in $\alpha-\mathrm{Fe})$ & 19.02 & 4.93 & 23.95 & - & 7.916 & - \\
\hline $\begin{array}{c}\mathrm{Fe} \\
\text { (in } \mathrm{FeAl} \text { ) } \\
\end{array}$ & - & - & - & - & $\begin{array}{c}6.932 \\
(6.968) \\
\end{array}$ & $\begin{array}{c}+0.2362 \\
(+0.2275)\end{array}$ \\
\hline $\begin{array}{c}\mathrm{Fe}(\mathrm{I}) \\
\left.\text { (in } \mathrm{Fe}_{3} \mathrm{Al}\right)\end{array}$ & $\begin{array}{c}21.65 \\
(21.33)\end{array}$ & $\begin{array}{c}2.15 \\
(2.23)\end{array}$ & $\begin{array}{c}23.79 \\
(23.55)\end{array}$ & $\begin{array}{l}-0.16 \\
(-0.40)\end{array}$ & $\begin{array}{c}7.996 \\
(8.069)\end{array}$ & $\begin{array}{c}-0.0192 \\
(-0.0367)\end{array}$ \\
\hline $\begin{array}{c}\mathrm{Fe}(\mathrm{II}) \\
\left.\text { (in } \mathrm{Fe}_{3} \mathrm{Al}\right)\end{array}$ & $\begin{array}{c}16.00 \\
(16.95)\end{array}$ & $\begin{array}{c}2.86 \\
(2.55)\end{array}$ & $\begin{array}{c}18.86 \\
(19.42)\end{array}$ & $\begin{array}{l}-5.09 \\
(-4.54)\end{array}$ & $\begin{array}{c}7.168 \\
(7.180)\end{array}$ & $\begin{array}{c}+0.1795 \\
(+0.1766)\end{array}$ \\
\hline
\end{tabular}

neighbour $\mathrm{Al}$ atoms, the intraatomic conversion is negligible. Within the "zero step potential" approach (potential step less than $10^{-5} \mathrm{Ry}$ ) the resulted picture of electron transfers is more complicated. Strong interatomic electron transfer is observed between constituents of unit cell. In $\mathrm{FeAl}$ compound iron atom gains 0.688 electrons at the cost of $2 s p$ electrons of aluminium atom. From these 0.688 electrons 0.494 goes to the $3 d$ band of Fe. The number of $4 s$ electrons of Fe increases only 
slightly (by 0.0417$)$. It means that the intraatomic conversion process $(4 s p-3 d)$ takes place in $\mathrm{Fe}$ atom. In $\mathrm{Fe}_{3} \mathrm{Al}$ compound we observe the electron interatomic transfer from $\mathrm{Al}$ and $\mathrm{Fe}(\mathrm{I}) \mathrm{W}-\mathrm{S}$ spheres to the $\mathrm{Fe}(\mathrm{II})$ one. A toms $\mathrm{Al}$ and $\mathrm{Fe}(\mathrm{I})$ lose 0.531 and 0.295 electrons, respectively. Consequently each of the $\mathrm{Fe}(\mathrm{II})$ atoms gains 0.413 electrons. Analysis of changes of partial occupation numbers in $\mathrm{Fe}(\mathrm{I}), \mathrm{Fe}$ (II) and $\mathrm{Al} \mathrm{W-S}$ spheres showed that the interatomic electron transfer to $\mathrm{Fe}$ (II) is associated with the intraatomic $4 s p-3 d$ conversion process at $\mathrm{Fe}(\mathrm{II})$ site. Effectively we found $Q_{s}=0.042, Q_{d}=0.494$ for $\mathrm{Fe}$ in $\mathrm{FeAl}, Q_{s}=-0.065, Q_{d}=-0.121$ for $\mathrm{Fe}(\mathrm{I})$ and $Q_{s}=0.0258, Q_{d}=0.255$ for $\mathrm{Fe}(\mathrm{II})$ in $\mathrm{Fe}_{3} \mathrm{Al}$.

In Table II the calculated values of hyperfine field $B_{\mathrm{hf}}$, the changes of hyperfine field $\Delta B_{\text {hf }}$ relatively to $\alpha$-Fe, charge density at $\mathrm{Fe}$ nucleus $\rho(0)$ and the isomer shift $\Delta I S$ for $\alpha-\mathrm{Fe}, \mathrm{FeAl}$ and $\mathrm{Fe}_{3} \mathrm{Al}$ are given. The calculated values are in good quantitative agreement with the experimental ones. The measured hyperfine field for $\mathrm{Fe}_{3} \mathrm{Al}$ is $23.55 \mathrm{MA} / \mathrm{m}$ and $16.80 \mathrm{MA} / \mathrm{m}$ for $\mathrm{Fe}(\mathrm{I})$ and $\mathrm{Fe}(\mathrm{II})$, respectively. The changes of isomer shift measured on $\mathrm{Fe}$ atom in $\mathrm{FeAl}$ compound is equal to $0.28 \mathrm{~mm} / \mathrm{s}$ [4]. Small negative value of $\Delta I S$ obtained for $\mathrm{Fe}(\mathrm{I})$ in $\mathrm{Fe}_{3} \mathrm{Al}$ differs in sign from the experimental results presented by Frackowiak [4], although it was reported that the isomer shift observed in Fe-Al alloys on iron surrounded by eight $\mathrm{Fe}$ atoms can be small negative $(-0.08 \mathrm{~mm} / \mathrm{s})[11]$.

The calculations of electron transfer on different type of $\mathrm{Fe}$ atoms in $\mathrm{FeAl}$ and $\mathrm{Fe}_{3} \mathrm{Al}$ compounds are in qualitative agreement with experimental ones. The different kinds of electron transfer proposed in $[3,4]$ are also strongly supported. It was found that for the calculated values of $Q_{s}$ and $Q_{d}$ the enhancement of the $d$-screening part within the formula of "additive model" for isomer shift yields the results which agree qualitatively with experiment.

\section{References}

[1] S. Ishida, J. Ishida, S. Asano, J. Yamashita, J. Phys. Soc. Japan 41, 1570 (1976).

[2] J.E. Frąckowiak, Hyperfine Interact. 54, 793 (1990).

[3] J.E. Frąckowiak, in: Proc. XXVI Zakopane School on Physics, Eds. J. Stonek, A.T. Pędziwiatr, World Scientific, Singapore 1991, p. 346.

[4] J.E. Frąckowiak, Nukleonika 39, 223 (1994).

[5] Ch. Müller, W. Blau, P. Ziesche, Phys. Status Solidi B 116, 561 (1983).

[6] B.I. Min, T. Oguchi, H.J.F. Jensen, A.J. Freeman, J. Magn. Magn. Mater. 54-57, 1091 (1986).

[7] M.E. Elzain, A.A. Yousif, Hyperfine Interact. 94, 1873 (1994).

[8] O.K. Andersen, O. Jepsen, D. Glötzel, in: Highlights of Condensed Matter Theory, Eds. F. Bassani, F. Fumi, M.P. Tosi, North-Holland, Amsterdam 1985, p. 59.

[9] S. Blügel, H. Akai, R. Zeller, P.H. Dederichs, Phys. Rev. B 35, 3271 (1987).

[10] O. Eriksson, J. Sjöström, B. Johansson, L. Häggström, H.L. Skriver, J. Magn. Magn. Mater. 74, 347 (1988).

[11] B. Fultz, Z.-Q. Gao, H.H. Hamdeh, S.R. Oliver, Phys. Rev. B 49, 6312 (1994). 